\title{
The Impact of Products Variety on Performance in the Iranian Cement Industry
}

\author{
Maryam Sadat Tabatabaeian
}

Faculty members of golpayegan Payame Noor University

\author{
Doi:10.5901/mjss.2016.v7n5s1p162
}

\begin{abstract}
Business units look for expedients such as variety of business and services offered to customers in order to survive and compete in a competitive economy and meet multiple needs of customers. On the other hand, diversification of the business and activities of the company can be troublesome containing costs and problems for the company. Increasing importance in explaining changes in a variety of industries and organizations causes different and wide range of social science research in the field. In this study, the effect of variations in the products of cement companies of Tehran capital market and their performance are evaluated. By performance we mean the company's liquidity, the ability to pay the debt by the company, the efficiency in the use of resources, and the profitability of the company. The results showed just significant effect on the firm use of resources efficiency caused by the variety of products.
\end{abstract}

Keywords: liquidity ratio, debt ratio, efficiency ratio, profitability ratio, diversity

\section{Introduction}

There is more competition in the world today, with diverse and rapid changes (the main goal). Also, many larger organizations in the world increase their business environment. Perhaps one of the reasons for this is to meet the needs of customers. Managers try to meet the needs of customers to make them loyal. For this reason and other technical reasons such as to preparing raw materials and finishing and distribution of products within organization, many of them have turned to diversity.

\section{Problem Definition}

Organizations should be able to survive in the competitive economy, improve their performance, increase their customers, and absorb more and increase their loyalty. One way to accomplish this is to diversify the business and services to customers. In the latter half of the twentieth century, because of specialized companies vulnerable to rapid changes and unexpected environment, diversity is assumed essential for growth and survival. Considering the increasing importance in explaining changes in a variety of organizations and industries, a wide range of social science research in various fields have been developed (Didar et al., 2014). On the other hand, diversity of the business and activities of the company can be troublesome containing costs and problems for the company. The question that may arise in the minds of managers is what the impact of diversity on the company's performance is? Financial ratios of the company's performance can be defined in four categories and measured, and then the relationship between diversity and business performance should be evaluated.

So the research question can be expressed as follows:

what is the likely impact of diversity on the company's performance?

\section{Objectives and Outcomes of Research}

The main objective of the research is considering the effect of diversification on the financial performance of the cement companies of Tehran capital market. Do the results prove that the companies diversify their business to improve their performance? And can better management help companies to improve their business planning?

\section{History}

Fazlzadeh et al. (2014) examined the relationship between diversity, capital structure, free cash flow, and performance of companies listed Tehran's Stock Exchange. The findings indicate that there is a positive correlation between the diversity 
of product and capital structure, also between the free cash flow and a variety of non-product. In addition, there is not a significant correlation between the products variety with the performance of listed cement companies in Tehran Stock Exchange.

Sheikh et al. (2014), using a variety of statistical tests, evaluated the relationship between the independent variables and financial ratios as the dependent variable. The results showed no relationship between the diversity of business and financial ratios.

HassasYeganeh did a research on the relationship between institutional investors and corporate values, and concluded that there is no significant correlation between the concentration of ownership of institutional and corporate value. Kang et al. (2011) found an inverse relationship between the degree of diversification of products, performance products, and supplements (Didar et.al, 2014).

Nat et al. (2010), using the resource-based view of strategy (RBV), evaluated the effect of diversity on the performance of 120 Logistics Companies. The results showed that companies that are market-oriented and provide a variety of products and services perform better than companies that have limited products and services.

\section{Theoretical Foundations}

According to the Ramanujam and Varadarjan(1989) diversity is to the extent that institutions operate simultaneously, at different business activities. The first point is the nature of diversity in the company (Raganatan, 1995). There are three levels of diversity:

1. Diversity of closely related products, 2. Diversification based on core competence, 3. Diversity of unrelated products (Didar et al., 2014)

Industries have a broad competition; market power is distributed among several firms, it is high compared with its industry concentration; more product is produced with relatively lower prices of goods and services. In other words, considering the share of products in diverse business industries, the result is better performance and lower prices. Liquidity, debt repayment capacity, performance, use of resources, and profitability can be calibrated. Therefore, subresearch hypothesis is as follows: the liquidity situation is better, better able to repay the debts; the better the use of their resources the better the profitability situation.

\section{Research Hypotheses and Questions}

The research question is that "can diversification strategy effect on the financial performance of the cement companies of Tehran capital market?"

The main hypothesis:

Companies that use diversification strategy have better performance.

Performance was measured by some criteria such as liquidity situation, ability to pay debt, use of resources efficiency, and profitability. So sub-research hypothesis is as follows:

- $\quad$ Companies that use diversification strategy have better liquidity situation.

- $\quad$ Companies that use diversification strategy have better ability to repay their debts.

- $\quad$ Companies that use diversification strategy have better use of resources efficiency.

- $\quad$ Companies that use diversification strategy have better profitability.

\section{Conceptual Framework}

The following conceptual framework is provided for analyzing the relationship between diversity and performance (Tehrani, 2007).

In this study, a variety of independent variables and dependent variables are financial ratios, adjusted for other variables that must be considered in applying the strategy of diversification between industrial and organizational fit. They fit between diversity, and four organizational factors were examined: organizational structure, organizational systems, organizational culture, and management features.

\section{Research Methodology}

The purpose of this research in terms of application and on the basis of the literature review is to study the impact of the company's business diversification strategy as financial ratios such as liquidity ratios, leverage ratios, efficiency ratios, and profitability ratios on the financial performance. 


\section{Research Variables}

If we consider the independent variable as $y$ and the dependent variables including an Acid ratio (to determine the company's liquidity position), debt ratio (debt to be determined by the company), asset turnover ratio (to determine the performance of the company's use of resources), and the ratio of the gross profit margin (profit for the company) as $\times 1$, $\mathrm{x} 2, \mathrm{x} 3$ and $\mathrm{x} 4$, the overall research model will be as follows:

$y=f_{1}(x)$

$X$ means the lack of variety or diversity. If the ratio of sales of the larger product to total sales is less than $70 \%$, the company is diversified, and if it is more than $70 \%$, it is not diversified.

\section{Statistical Population}

The statistical population is all cement companies listed in the Tehran Stock Exchange, which are also eligible.

1. In the study period (years 2007 to 2013) are not out of stock;

2. Have information needed for the period of the study (years 2007 to 2013). The remaining companies having available all information is 27 companies.

\section{Data Collection Method}

1. For literature review, library research papers and theses were used at home and abroad.

2. To gain information on dependent and independent variables in the model, new outcomes of the research referred to the software were used.

3. Internet browsing and reading documents were also useful.

\section{Data Analysis Method}

A statistical method and the significant level of $5 \%$ were used to accept or reject the hypotheses. After collecting data using Excel and SPSS software, the analysis of the relationship between variables was performed. To compare the dependent variables in companies with diversified products and other products of various companies for two independent samples, t-test was used.

\section{Results}

The statistical hypotheses according to the research hypotheses are:

$\mathrm{HO}$ : Average of the target variable in invariant companies Average of the target variable in diversified companies $\mathrm{H} 1$ : Average of the target variable in invariant companies Average of the target variable in diversified companies. Mathematically Hypothesis is:

$\mathrm{H}_{0}: \mu 1 \leq \mu 2$

$\mathrm{H}_{1}: \mu 1>\mu 2$

The table below shows the standard deviation of the dependent variables in the study:

Table 1. Standard deviation of the dependent variables

\begin{tabular}{|c|c|c|}
\hline Dependent Variables & Group Type & S.td \\
\hline \multirow{2}{*}{ Quick Ratio } & diversified companies & 4.6 \\
\cline { 2 - 3 } & Invariant companies & 26.8 \\
\hline \multirow{2}{*}{ Debt Ratio } & diversified companies & 1.7 \\
\cline { 2 - 3 } & Invariant companies & 0.68 \\
\hline \multirow{2}{*}{ Asset Turnover Ratio } & diversified companies & 19.66 \\
\cline { 2 - 3 } & Invariant companies & 3.9 \\
\hline \multirow{2}{*}{ Gross profit margin Ratio } & diversified companies & 0.17 \\
\cline { 2 - 3 } & invariant & 0.04 \\
\hline
\end{tabular}

The results of the hypothesis test are as follows: 
Hypotheses include a main hypothesis and four sub-hypotheses for testing four dependent variables $(x 1, x 2, x 3$, and $\times 4)$ and an independent variable that indicates the presence or absence of diversity in company consideration ( $0=$ lack of variety and 1= diversity). In order to do any test, data should be normal. KS test was performed to check the normality of the data, and the results are as following:

Table 2. KS Test output

\begin{tabular}{|c|c|c|c|c|c|}
\hline \multicolumn{6}{|c|}{ One-Sample Kolmogorov-Smirnov Test } \\
\hline \multirow{2}{*}{$N$} & X1 & X2 & X3 & X4 \\
\hline \multirow{2}{*}{ Normal Parametersa } & & 27 & 27 & 27 & 27 \\
\hline \multirow{3}{*}{ Most Extreme Differences } & Mean & 4.7663 & .6914 & -2.5632 & .4449 \\
\cline { 2 - 6 } & Std. Deviation & 22.06904 & 1.09037 & 12.74905 & .10555 \\
\cline { 2 - 6 } & Absolute & .436 & .268 & .372 & .285 \\
\cline { 2 - 6 } & Positive & .436 & .250 & .226 & .285 \\
\cline { 2 - 6 } & Negative & -.312 & -.268 & -.372 & -.209 \\
\hline \multicolumn{2}{|c|}{ Kolmogorov-Smirnov Z } & 2.264 & 1.392 & 1.933 & 1.481 \\
\hline Asymp. Sig. (2-tailed) & .000 & .041 & .001 & .025 \\
\hline \multicolumn{2}{|c|}{} & & & \\
\hline
\end{tabular}

As shown in the above output, Sig of KS test on the level $95 \%$ is smaller than $5 \%$, and normality ofdata is confirmed. So after making sure that the range of test research statistical hypothesis is normal, statistical hypothesis test is stated as follows:

The first sub-hypotheses:

Companies that use diversification strategy have better liquidity situation.

Table 3. T-test results for sub-hypothesis 1

\begin{tabular}{|c|c|c|c|c|c|}
\hline Acid ratio & Mean & Std. Deviation & $t$ & $d f$ & $p$-value \\
\hline diversified Group & 0.1341 & 4.58814 & \multirow{2}{*}{0.765} & 25 & \multirow{2}{*}{0.451} \\
\hline Invariant Group & 7.0823 & 26.7945 & & & \\
\hline
\end{tabular}

Instant comparison of two independent samples test for acid ratio (i.e. companies with diversified products and companies that have not diversified products) with $25 \mathrm{as} \mathrm{df}$, showed the t-statistic value being 0.765 , since the level of $95 \%$ statistics p-value is greater than $5 \%$, so the assumption $\mathrm{HO}$ is not rejected. It means that there is no difference between the liquidity of companies with diversified products and companies with invariant products.

The second sub-hypotheses:

Companies that use Diversification strategy have better ability to repay their debts.

Table 4. T-test results for sub-hypothesis 2

\begin{tabular}{|c|c|c|c|c|c|}
\hline debt ratio & Mean & Std. Deviation & $t$ & $d f$ & $p$-value \\
\hline diversified Group & 0.9536 & 1.667 & \multirow{2}{*}{0.88} & 25 & 0.387 \\
\hline Invariant Group & 0.5602 & 0.67532 & 0 & 25 \\
\hline
\end{tabular}

Instant comparison of two independent samples test for acid ratio (i.e. companies with diversified products and companies that have not diversified products) with 25 as df, showed the t-statistic value being 0.88 , since the level of $95 \%$ statistics p-value is greater than $5 \%$, so the assumption $\mathrm{HO}$ is not rejected. It means that there is no difference between the liquidity of companies with diversified products and companies with invariant products.

The third sub-hypotheses:

Companies that use Diversification strategy have better Use of resources Efficiency. 
Table 5. T-test results for sub-hypothesis 3

\begin{tabular}{|c|c|c|c|c|c|}
\hline asset turnover ratio & Mean & Std. Deviation & $t$ & $d f$ & $p$-value \\
\hline diversified Group & -10.6198 & 19.6574 & \multirow{2}{*}{-2.557} & 25 & 0.017 \\
\hline Invariant Group & 1.4652 & 3.8988 & & \\
\hline
\end{tabular}

Instant comparison of two independent samples test for acid ratio (i.e. companies with diversified products and companies that have not diversified products) with 25 as df, showed the t-statistic value being -2.557 , since the level of $95 \%$ statistics $p$-value is smaller than $5 \%$, so the assumption $\mathrm{HO}$ is rejected. It means that there is significant difference between the liquidity of companies with diversified products and companies with invariant products.

The fourth sub-hypotheses:

Companies that use Diversification strategy have better profitability.

Table 6. T-test results for sub-hypothesis 4

\begin{tabular}{|c|c|c|c|c|c|}
\hline gross profit margin ratio & Mean & Std. Deviation & $t$ & $d f$ & $p$-value \\
\hline diversified Group & 0.4924 & 0.16999 & \multirow{2}{*}{1.712} & 25 & \multirow{2}{*}{0.099} \\
\hline Invariant Group & 0.4212 & 0.04062 & & & \\
\hline
\end{tabular}

Instant comparison of two independent samples test for acid ratio (i.e. companies with diversified products and companies that have not diversified products) with 25 as df, showed the t-statistic value being 1.712, since the level of $95 \%$ statistics $p$-value is greater than $5 \%$, so the assumption $\mathrm{HO}$ is not rejected. It means that the difference between the liquidity of companies with diversified products and companies with invariant products.

The results showed just significant effect on the firm use of resources efficiency caused by the variety of products.

\section{Discussion and Conclusion}

The results of this study correspond with the results of Thrani et al. (2007) and Sheikh et al. (2012). Also some researchers have found a negative relationship between diversity and performance in research. Deniz (2002) also found that the effects of industrial diversity on the value of the company are negative. In contrast, other studies have described the relationship between diversity and performance, indicating positive results. Didar et al. (2014) concluded that a variety of business had a significant impact on the performance of the companies under investigation. Penrose (1959) and Maris (1964) argue that companies grow and maximize shareholder value, diversify assets (Tehrani, 1999).

\section{References}

Armstrong, C; Flood, P C; Guyhrie, J P ; et al., 2010,the impact of diversity and equality management on firm performance: beyond high performance work systems, Human Resource Management journal, November-December 2010, Vol 49, No 6, pp 977 - 998.

Baldwin, J R; Beckstead, D; Gellatly, G; Peters, A, June 2000, Patterns of Corporate Diversification in Canada: An Empirical Analysis, Analytical Studies Research Paper Series, 11F0019MPE No. 150.

BÄar, M; Niessen, A; Ruenzi, S, September 2007,The Impact of Work Group Diversity on Performance: Large Sample Evidence from the Mutual Fund Industry,CFR-Working Paper, NO. 07-16.

Brost A; Kliner H, 1995, New Developments in Corporate Diversification Strategies, Management Research News, Vol 18, No 3-5.

Didar, H; Imani B, M; Shahrezaie, S., 2014, Impact of variety of business on performance and value of Tehran capital exchange companies, assets management and financing, second year, NO2.

Doukas, J.; Holmen, M.; Travlos, N., February 2001, Corporate Diversification and Firm Performance: Evidence from Swedish Acquisitions, -SSRN Electronic Journal 02/2001; DOI: 10.2139/ssrn.250520.

Fazlzadeh, A; Khanlary, M; Teymuri, H., 2014, Study of relationship between variety of business, capital structure, free cash course and performance of Tehran capital exchange companies, National conference of new methods in business management.

Grant, R., 1988, Diversity, Diversification and Profitability among British Manufacturing Companies, Academy of Management Journal, Vol. 31, No. 4.

Kruse, T.; Park, H.; Park, K.; Suzuki, K.; March, 2002, The Value of Corporate Diversification: Evidence from Post-Merger Performance in Japan, -SSRN Electronic Journal 03/2002; DOI: 10.2139/ssrn.344560.

Martynova, M.; Oosting, S.; Renneboog, L., November 2006, The Long-Term Operating Performance of European Mergers and 
Acquisitions, ECGI Working Paper Series in Finance, -SSRN Electronic Journal 02/2006; DOI: 10.2139/ssrn.944407.

Mathur, I.; Sang Kim, Y., 2008, The Impact ofgeographicDiversification on Firm Performance, International Review of Financial Analysis, Vol 17, Issue 4, pp747-766.

Nath, P.; Nachiappan, S.; Ramanathan, R., 2010, The impact of marketing capability, operations capability and diversification strategy on performance: A resource-based view, Industrial Marketing Management, I/Nolume 39, Issue 2, February 2010, Pages 317329.

Sheikh, M J; Hemmati, H; Zamani G, M; Mohajerani, M., 2014, Study of impact of variety of business on financial performance of Tehran capital exchange companies, accounting and auditing research, NO 22.

Tehrani, R; Babaei Z, MA; Karimi, K., 2007, Impact of diversity strategy on Financial Performance of Tehran capital exchange companies, Financial studies, NO25. 